J. Contemp. East. Asia (ISSN 2383-9449) Vol. 1, No. 1, July 2002: 1

DOI: $h$ ttp://dx.doi.org/10.17477/jcea.2002.1.1.001

(eastasia.at ISSN 1684-629X)

\title{
KMT consistently urging Beijing not to engage in dialog with DPP government on unification issue
}

In March 2000, Chen Shui-bian of the

Democratic Progressive Party (DPP) won the presidential race and ousted the KMT from the presidency for the first time in history. Global economic decline, KMT dominance in parliament, and tensions between the nationstate of Taiwan and the People's Republic of China gave the opposition the opportunity to question the ability of the DPP to rule the nation. To make things worse for the DPP, the KMT has reportedly used its economic and political power to shed dark light on the DPP. Local media reports claimed that companies affiliated with the KMT had withdrawn capital and manipulated the stock market in order to discredit the DPP. Moreover, Bonnie S.

Glaser, a consultant on Asian affairs, stated in an article for the Center for Strategic and International Studies that the KMT had consistently urged Beijing not to engage in a dialogue with the new government in Taipei in an effort to weaken the position of the DPP and increase the chances of a KMT election victory in the December 2001 parliamentary election. Lin Fong-cheng, secretary general of the KMT, denied the accusations.

Article by Bonnie Glaser (http://www.csis.org/pacfor/pac0133.htm) Official KMT response (http://www.csis.org/pacfor/pac0133X.htm\#hamre) Bonnie S. Glaser's response (http://www.csis.org/pacfor/pac0133X.htm\#hamre) 